\title{
The Importance of Mineralogical Knowledge in the Sustainability of Artisanal Gold Mining: A Mid-South Peru Case
}

\author{
Pura Alfonso ${ }^{1, *(1)}$, Hernan Anticoi ${ }^{1}{ }^{\circledR}$, Teresa Yubero ${ }^{1}$, Marc Bascompta ${ }^{1}{ }^{1}$, Laura Henao ${ }^{2}$, \\ Maite Garcia-Valles ${ }^{3}$, Silvia Palacios ${ }^{1}$ and Juan Yáñez ${ }^{1}$ \\ 1 Departament d'Enginyeria Minera, Industrial i TIC, Universitat Politècnica de Catalunya Barcelona Tech, Av. \\ Bases de Manresa 61-63, 08242 Manresa, Barcelona, Spain; hernan.anticoi@upc.edu (H.A.); \\ maria.teresa.yubero@upc.edu (T.Y.); marc.bascompta@upc.edu (M.B.); silviapalacios19@hotmail.com (S.P.); \\ juanbarakaldo@gmail.com (J.Y.) \\ 2 Alliance for Responsible Mining-ARM, Calle 32 B SUR, 44 A 61 Envigado, Colombia; \\ laurahenao@responsiblemines.org \\ 3 Departament de Petrologia i Mineralogia Aplicada, Universitat de Barcelona, Carrer Martí i Franquès s/n, \\ 08028 Barcelona, Spain; maitegarciavalles@ub.edu \\ * Correspondence: maria.pura.alfonso@upc.edu; Tel.: +34-9-3877-7292
}

Received: 8 April 2019; Accepted: 3 June 2019; Published: 5 June 2019

check for updates

\begin{abstract}
Mineralogy and gold processing techniques from several mining areas of the Nazca-Ocoña gold belt, Mid-South Peru, were investigated to assess the efficiency of gold extraction methods in relation to their mineralogy. The deposits from this belt are intrusion gold related to mineralization in quartz veins. Native gold occurs as micrometric grains encapsulated in pyrite and in minor amounts in other sulfides and quartz. Electrum is found mainly in fractures of pyrite and attains up to $35 \mathrm{wt}$. $\%$ Ag. In addition to these occurrences, gold tellurides also occur and they are abundant in San Luis. Gold processing is carried out by amalgamation with mercury and/or cyanidation. The comparison of the gold grade in the mineralizations and in the residual tailings indicates that a significant amount of gold is not recovered using the mercury amalgamation process and also, in the case of the gold recovery by cyanidation, except when cement was added to the cyanide solution. This was due to an increase in the $\mathrm{pH}$ that favours the dissolution of the gold matrix. In the cyanidation process carried out in tailings previously treated with mercury, part of the mercury retained in them is released to the atmosphere or to the cyanidation fluids.
\end{abstract}

Keywords: artisanal mining; Peru; gold; amalgamation; cyanidation

\section{Introduction}

Artisanal gold mining (ASM) is a widespread activity that involves more than 15 million workers [1]. It was estimated that in 2013 there were about 16 million gold artisanal miners worldwide [2]. This number increased up to 20 million in 2017, which represents 50\% of the total number of artisanal and small-scale miners [3], with an estimated gold production between 380 and $450 \mathrm{t} / \mathrm{year}$ [2]. Artisanal gold represents between $20 \%$ and $30 \%$ of all the extracted gold in the world [4]. This ratio could be even higher because the commercial activities of artisanal mining are poorly ruled and information can be obtained from field surveys of miners and Artisanal Mining Associations, and from traders who buy gold directly from miners [2].

Gold mining is one of the most important economic activities in Peru, to the point that thanks to this activity Peru is no longer considered a developing country but an upper-middle income country [5-7]. Artisanal mining represents about $20 \%$ of the total gold produced in Peru [8] and involves about 
30,000 direct workers and 180,000 dependents [9]. According to the United Nations Environment Programme (UNEP) [10], these figures rise to 70,000 direct workers and 300,000 dependents. A significant proportion of these people are located in the Mid-south region of the country.

The term "artisanal" usually refers to mining that uses rudimentary techniques for mining exploitation and ore processing [11]. Artisanal mining takes place in conditions of informality, inefficient productivity, and environmental pollution. Artisanal miners commonly operate in high-grade gold mines with a low tonnage that are no longer profitable for large mining companies, as in the case of Misky and San Cristobal (Figure 1). Typically, these miners have no technical knowledge; they do not know the geology and mineralogy of the mining sites, and all the different processing techniques $[12,13]$. Thus, the methods used for gold recovery are probably not the most efficient ones to obtain the greatest economic benefits. The rational and optimized exploitation of a deposit is possible only if we know its geology, mineralogy, and the deposit type. On the other hand, the chemistry of minerals and the liberation characteristics allow for the selection of the most effective processing methods to maximize the recovery and prevent environmental pollution.

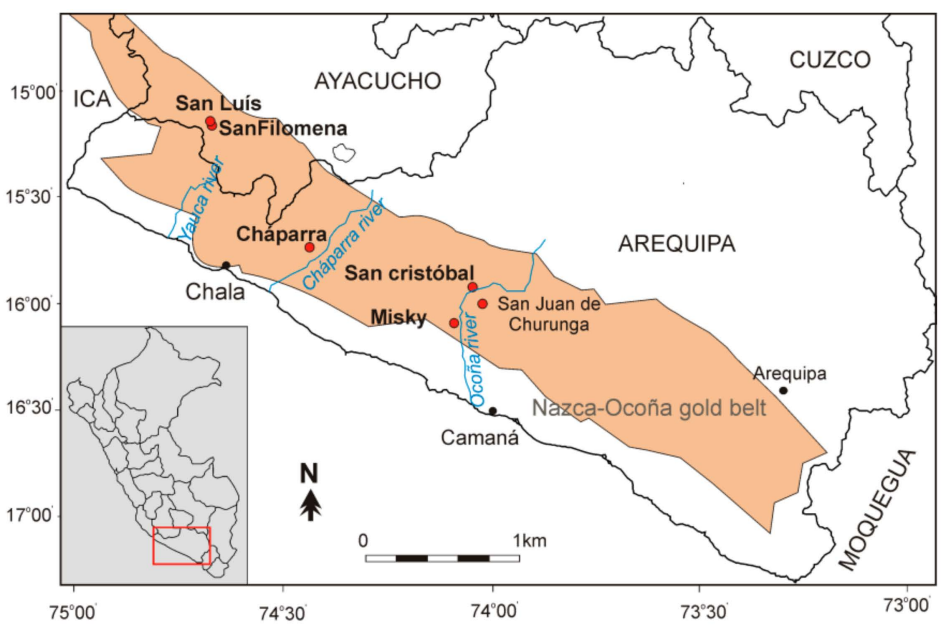

Figure 1. The location of the studied mining sites.

Furthermore, the ASM contributes significantly to the economy of developing countries and provides work for many of its inhabitants, with the creation of employment opportunities and poverty reduction [7,14-16]. Therefore, the conditions to develop the artisanal mining activity must be improved, optimizing the recovery process and minimizing environmental pollution. It is necessary to train the miners and show them the most appropriate processing techniques and how to carry them out. The training programs must be carefully designed [11,13]. However, for this, it is also necessary to know in detail the mineralogy of the ore and gangue from the mining sites.

A sustainable mine operation should be safe, economically profitable, efficiently use mineral resources and be environmentally clean [17]. Abundant scientific literature exists regarding the high environmental impacts produced by the artisanal gold mining worldwide [18-23]. However, another problem that greatly limits the sustainability of gold artisanal mining is the low productivity [24], mainly due to the low gold recovery after ore beneficiation that usually accompanies artisanal mining activities. This fact provides a strong argument to convince miners to change their processing methods by other more efficient and environmentally friendly ones. Several institutions and non-governmental associations explain to miners the pollution produced during their mining activity and the effects it has on both environmental and human health. However, this information does not encourage them to make changes to their methods. Miners will consider changing their practices if they perceived an increase in their economic benefits [11].

In the case of the artisanal mining of Peru, the relevant literature is limited to the Madre de Dios area [7], which produces about 70\% of the Peruvian ASM gold [25]. However, there is scarce 
information about the Mid-South Peru area, even though gold mining is the main economic activity there. This work presents a mineralogical and chemical characterization of gold ores and tailings from several locations of Mid-South Peru to identify the causes of the low gold recovery during the processing. The study shows how it is necessary to contribute with the knowledge of the mineralogy of materials extracted by artisanal miners to improve the performance of their methods and, thus, to contribute to do the activity more sustainably and to increase their economic benefits.

In this study, several study cases from settlements of the Nazca-Ocoña gold belt, located in the Ayacucho and Arequipa departments of Peru. In this area, the processing of gold ores is made by traditional methods, using amalgamation, cyanidation, or a combination of both methods. Usually, miners do not determine the mineralogy and liberation characteristics of the ore before planning the processing procedure.

Knowledge of mineralogy is essential to optimize the mineral processing of gold ores [26-30]. The ore mineralogy will determine the characteristics of the physical and chemical processes that result in the best recovery grade [31]. Gold can be found mainly as native gold, electrum, and gold tellurides, but submicroscopic gold can also be present in arsenopyrite and pyrite [32,33]. The mineralogical characteristics necessary for gold processing are mainly the identification of gold minerals, the determination of the mineral association with gold, and the morphology and grain size of gold minerals. These data are necessary to determine the liberation characteristics and the portion of invisible gold that is allocated in the structure of other minerals, such as sulphides [26,34].

The Nazca-Ocoña belt belongs to the Mid-South mining area, which covers the southern part of the Ica and Ayacucho departments and the northern part of the department of Arequipa [25]. The Polytechnic University of Catalonia has carried out different projects in several Peruvian mining sites. These projects have been supported by Red Social, and Sociedad Nacional de Minería en Pequeña Escala (SONAMIPE) and the Alliance for Responsible Mining Foundation (ARM). These associations have supported the Artisanal and Small-Scale Mining Organizations (ASMOs) in the identification of the main current weaknesses, building improvement actions with the miners and within the scope of the miners so that they can improve their organizational, economic, legal, environmental, working safety, and health and social conditions; seeking that the mining activity is developed socially and is environmentally responsible. Thanks to the previous support provided by the mentioned organizations, the miners have improved compliance with their legal obligations, in addition to obtaining Fair-mined Certification. This certification was created by the ARM and it is achieved by miners that produce gold with social and environmental responsibility, with the controlled use of chemicals, among other requirements $[35,36]$.

\section{Mining Sites}

\subsection{General Characteristics}

Five mining sites from the Nazca-Ocoña gold belt were selected for this study, three of them from the Arequipa department: Cháparra, Misky, and San Cristóbal and two from Ayacucho: San Luis and Santa Filomena (Figure 1).

Several mining exploitations have established their operation in the vicinity of Cháparra. This is the case of the small-scale mining company Minera Aurifera Cuatro de Enero S.A. (MACDESA). This company has been certified and received the Fairmined certification in 2017.

The mining area of Misky has been exploited by several companies from 1897 until 1914. Since 1995, small artisanal miners have exploited this area. Misky is located in a narrow w valley with very steep slopes, where several mines are excavated following gold veins. The population is located at the foot of the valley, in a constant risk situation given by the possibility of falling blocks from the exploitations. Gold is recovered by amalgamation in the processing area of San Martin, which is located $5 \mathrm{~km}$ from the Misky mining settlement. The remaining tailings are sold to a processing plant near the town of Chala. 
The San Cristóbal settlement is located 3950 m.a.s. (meters above sea level), and the mines are located at 3200 m.a.s. The accessibility to this place is difficult; the tarmacked road only reaches Torrepampa, and from here it takes about two hours of trekking down to reach to the mining site. The mining tools and the concentrate of the gold processing are transported on mules. Until recently, in San Cristóbal, amalgamation was the common practice. Due to the inaccessibility, tailings transportation is too expensive to sell them to other larger processing plants able to recover the remaining gold. Thus, to extract part of the gold still contained in the tailings, these were reprocessed by cyanidation. In San Cristóbal, miners abandoned the use of mercury and this was formalized in 2017.

San Luis and Santa Filomena are close to each other and both were exploited by the San Luis Gold Mines company. In the past, gold was recovered using mercury, but nowadays only cyanidation is used. In Santa Filomena, there are abundant veins exploited by different cooperatives. The biggest is the Sociedad de Trabajadores Mineros S.A. (SOTRAMI). However, in the present study, only the area exploited by the FIDAMI cooperative was considered. San Luis earned the Fairmined certification in December 2018. During the process of their certification and formalization, they have contributed to their community with electrification projects, support for education, and the strengthening of health.

In all these sites, mining operations consist of narrow tunnels excavated in hard rock along the veins and with a similar dip angle (Figure 2). In some cases, such as in Misky, some underground mines proceed from the used by the mining companies that exploited the area. Nowadays, a curious and inherently informal situation happens: different zones of the same cavity belong to different owners.
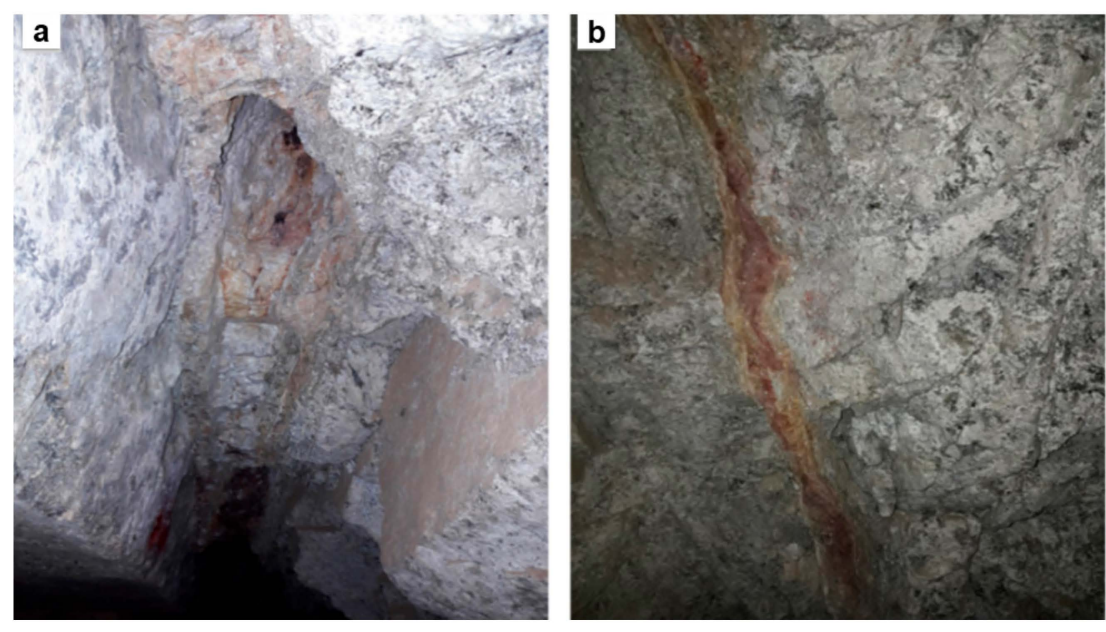

Figure 2. The underground mine of the Santa Filomena mining activity. (a) The roof of a gallery where most of the ore has already been extracted and (b) the area with the same vein before being exploited.

\subsection{Geology}

\subsubsection{Geological Setting}

Gold deposits from Mid-South Peru belong to the Nazca-Palpa-Ocoña gold belt, which stretches more than $350 \mathrm{~km}$ along the southern part of the Coastal Batholith. This batholith is constituted by numerous Mesozoic plutonic bodies and crops out almost continuously along the Western Cordillera of Peru, extending more than $1600 \mathrm{~km}$ parallel to the coast and is more than $65 \mathrm{~km}$ wide [37]. This Batholith is divided into five segments that, from north to south are Piura, Trujillo, Lima, Arequipa, and Toquelapa.

The Nazca-Palpa-Ocoña gold belt belongs to the Arequipa segment, which, in turn, is constituted by five super-units [38]. The Patap Super-unit is made up of gabbro; the Linga Super-unit is composed of rocks between monzodiorite and monzogranite; the Pampahuasi Super-unit is composed of tonalities; the Incahuasi Super-unit represents the largest volume of the batholith and is comprised of large plutons consisting mainly of monzodiorites. Finally, the Tiabaya Super-unit is the youngest and 
most important of the five, as it outcrops along the entire Arequipa segment, showing cross-sectional relationships with all previous intrusions. The lithology varies from diorites to monzogranites, with granodiorites being the most abundant rocks. The age of this segment is between $102 \mathrm{Ma}$ and 80 Ma [38].

The Nazca-Palpa-Ocoña gold belt has more than 70 deposits [39,40]. Among them, the Misky, or Posco-Misky, San Cristóbal, Cháparra, San Luis, and Santa Filomena are presented in this study (Figure 1). Other deposits are the Calpa, Ishihuinca, Ocoña, Sol de Oro, Los Incas and San Juan de Churunga [41]. Cháparra is located in the Linga Super-unit and the rest of the ore deposits presented here are located in the Tiabaya Super-unit. In the studied area, these units are hosted and covered by sedimentary rocks of Jurassic to Miocene age and Pliocene and Quaternary sands and gravels.

From the metallogenic point of view, Peru is divided into 23 belts, 12 of them are gold belts, and the studied area belongs to belt IX, corresponding to $\mathrm{Au}-\mathrm{Pb}-\mathrm{Zn}-\mathrm{Cu}$ intrusion-related deposits of Upper Cretaceous age. This belt is divided into three areas, one of them is the Nazca-Ocoña [42].

\subsubsection{Gold Mineralization}

Based on regional field criteria, Sillitoe and Thompson [43] classified the deposits of the Nazca-Palpa-Ocoña belt as being of the Intrusion-Related (IRGD) type. Although other authors classified these deposits as orogenic or mesothermal [44,45], the geochemical characterization of the Misky deposit showed that this mineralization exhibits the main characteristics of the IRGD [46].

In this belt, the gold mineralization occurs in fault-controlled quartz veins mainly hosted in plutonic or sub-volcanic rocks. Veins are filled by quartz but, in some cases, they have a reddish colour due to the abundance of Fe-oxides. In other cases, sulfide-rich mineralization accompanies quartz (Figure 3).
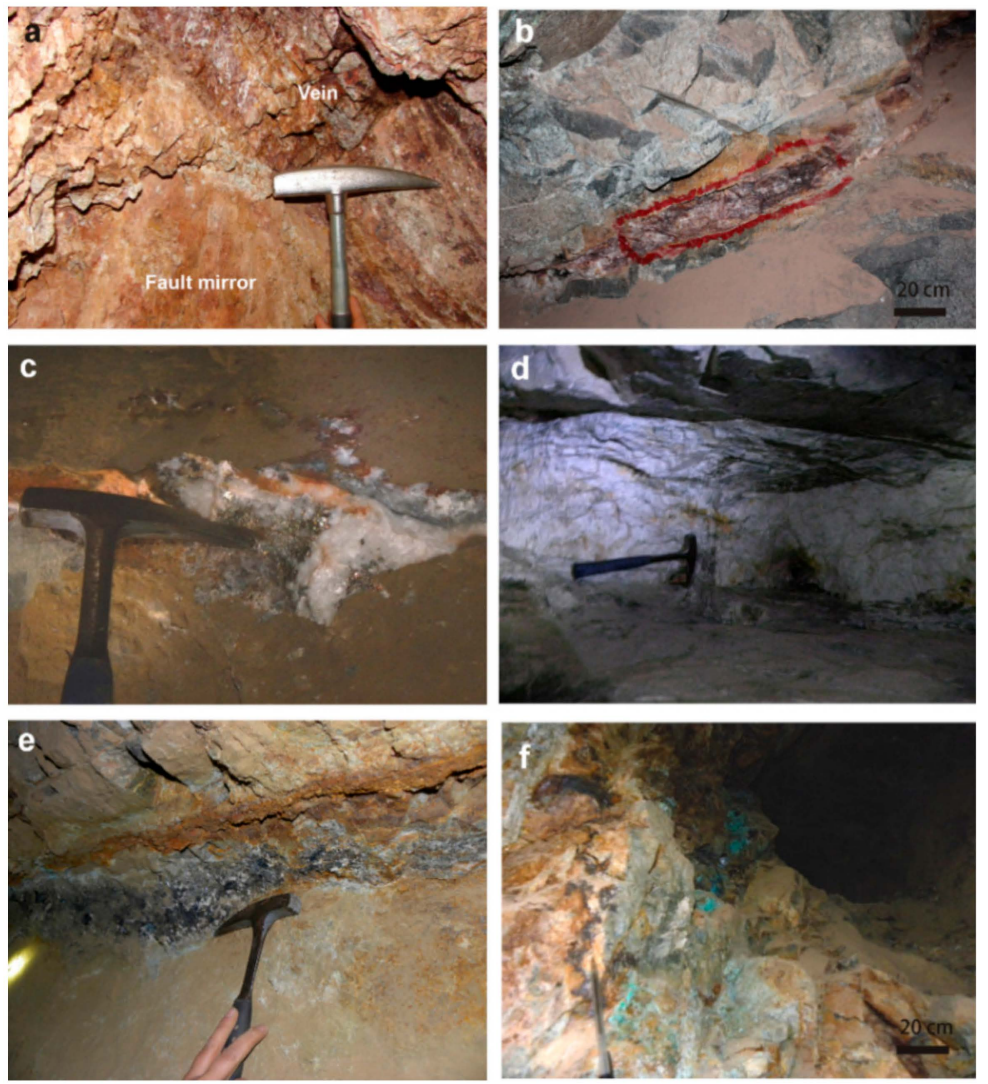

Figure 3. The veins from gold mineralization of the Nazca-Ocoña belt. (a) Cháparra Fe-rich vein, (b) San Luis vein, (c) sulfide-rich vein from Misky, (d) typical massive quartz vein from Misky, (e) sulfide-rich vein from San Cristóbal, (f) Au, Cu-rich mineralization from San Cristóbal. 
Veins are usually less than $1 \mathrm{~m}$ thick with NW-SE, N-S, and W-E orientations. NW-SE veins are the longest and have from $70^{\circ}$ to nearly vertical dip. W-E veins cut the NW-SE veins and dip around $45^{\circ}$. Veins are usually beaded and although they can occur over a long distance, they are often cut by faults. This made it difficult for miners to follow the excavation of the underground mine along the vein. In this case, the miners usually say that the vein "has disappeared" and the absence of detailed geological maps make difficult to locate them again.

Hydrothermal alteration is associated with the mineralizations, and sericitization, chloritization, and silicification can be abundant in the vicinity of the veins.

\subsection{Mineral Processing}

Mining exploitation in the area is mainly carried out underground. The excavation is made with the use of mechanical drills and explosives. The ore is extracted in fragments of about $5 \mathrm{~cm}$ in diameter that are transported to a processing area located in the same communal living areas or in other places specifically designed for this task.

Artisanal miners from Mid-South Peru use two methods for gold processing. The amalgamation with $\mathrm{Hg}$ was the common practice some years ago, but currently, in many mine sites, it has been replaced by the cyanidation method. When gold is processed by amalgamation, the first stage of comminution is necessary. The reduction of the particle size is obtained by ball mills or, more frequently, by handmade mills, the so-called quimbaletes. This rudimentary mill is a kind of large mortar composed of a sink in which the gold ore is placed and a stone with a slightly oval-shaped base acts as a mallet. A board is placed on it, upon which a person climbs to move the stone mallet and grind the material (Figure 4). Mercury can be added together with the ore or later, once the material is milled, in order to react with the gold to form the amalgam. Most miners do not have mills and they have to rent the quimbaletes, often in exchange for the tailings produced. The amalgam of mercury and gold is manually isolated from the residual tailings. Gold is separated from $\mathrm{Hg}$ by burning the amalgam outdoors or in spaces prepared for it using retorts, which in the studied area belong usually to the community. During the burning, the mercury evaporates and the gold is obtained. In the case of the use of retorts, some of the mercury is condensed and recovered to be recycled, but the other portion goes directly into the atmosphere.
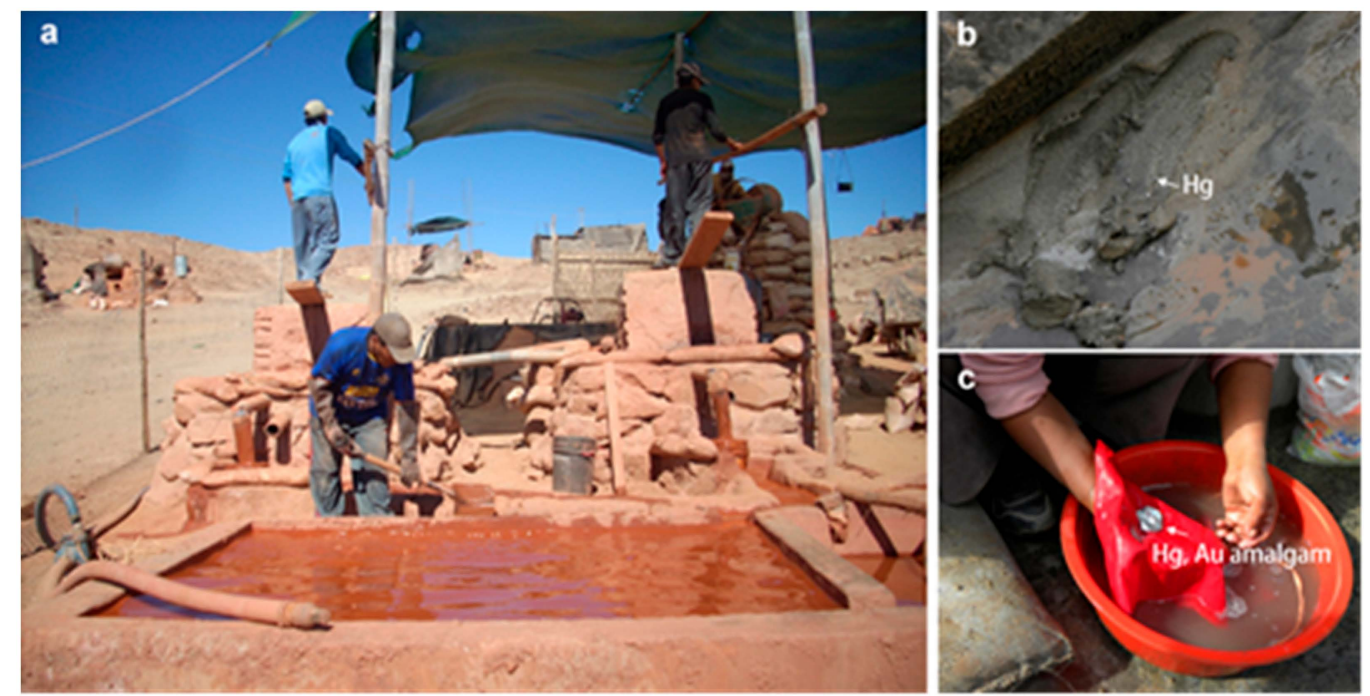

Figure 4. Gold recovery by artisanal miners in the Nazca-Ocoña area. (a), grinding with the mill quimbalete; (b) Hg-rich concentrate; (c) miner obtaining the amalgam.

In some cases, after the recovery of gold by means of amalgamation with mercury, miners use cyanidation in the resulted tailings to recover the remaining gold. However, nowadays cyanidation is the only process implemented in many of the visited mining sites (Figure 5). 

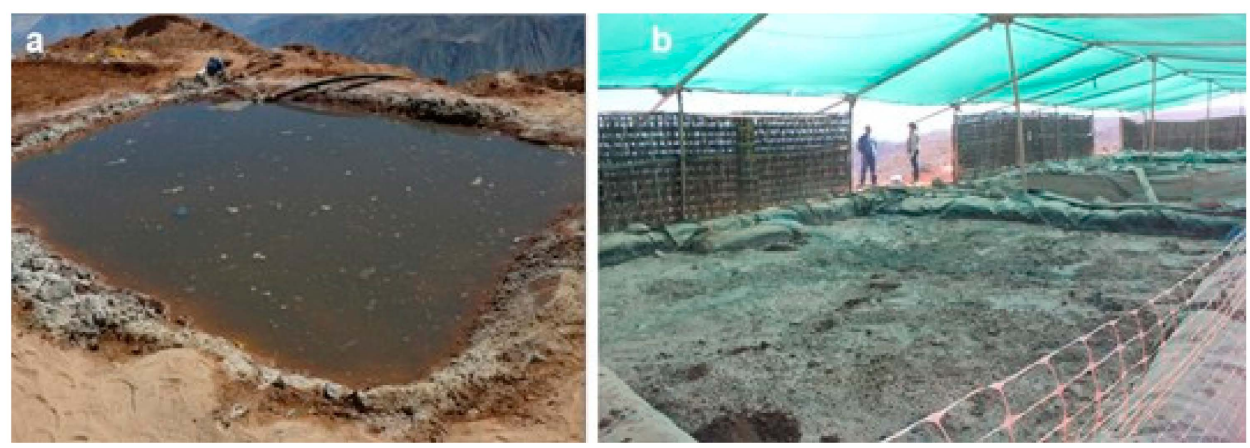

Figure 5. Cyanidation ponds. (a) San Cristobal, image from 2010, (b) In San Luis, the ponds are covered.

The cyanidation process is carried out in waterproofed ponds where the ore is placed together with a cyanide solution. After $24-48 \mathrm{~h}$ the waterproof membrane has channelled the leachate of gold cyanide and it is transported to tanks. In them, activated carbon is added and left to stand for a week so that the reaction of the carbon with the gold in solution is produced.

In the case of San Luis and other plants in the area, such as Relave, the grounded ore is mixed with cement to carry out the cyanidation. This leads to the pelletization of the ground ore. Miners add cement to avoid the agglomeration of the very fine particles and increase the porosity to facilitate the circulation of the cyanide solution.

\section{Materials and Methods}

Samples were obtained from the underground mines, the run of mine ore (ROM), and the different tailings. The sampling sites were Misky and their processing area of San Martín, San Cristóbal, Cháparra, San Luis, and Santa Filonema (Table 1).

Table 1. Location of the materials analysed in the present study using coordinates UTM (WGS-84, zone 18L).

\begin{tabular}{ccccc}
\hline Department & Location & Material & Vein/Mine & Coordinates (UTM) \\
\hline \multirow{4}{*}{ Arequipa } & Misky & Ore/ROM & Charpera & $693,031 / 8,233,564$ \\
& Misky & Ore & Nivel 950 & $693,176 / 8,233,423$ \\
& Misky & Ore & Soledad & $693,890 / 8,233,267$ \\
& Misky & Ore & 7 bocas & $693,663 / 8,233,808$ \\
& Misky & Ore & Posta & $693,795 / 8,233,681$ \\
& San Martín & Tailings & & $692,507 / 8,235,121$ \\
& San Cristóbal & ROM & & $718,850 / 8,265,624$ \\
& San Cristóbal & Tailings & & $719,055 / 8,265,415$ \\
\hline & Cháparra & Ore & Macdesa & $619,113 / 8,263,400$ \\
& Cháparra & Ore & Aurex & $622,896 / 8,260,510$ \\
& Cháparra & Ore & Alto Perú & $626,568 / 8,258,890$ \\
& San Luis & Ore & Clider/principal & $576,757 / 8,304,716$ \\
& San Luis & ROM & & $576,488 / 8,304,588$ \\
& San Luis & Tailings & & $577,608 / 8,300,549$ \\
& Santa Filomena & Ore & ANA/Anampa & \\
& Santa Filomena & ROM & & $577,608 / 8,300,550$ \\
\hline
\end{tabular}

Whole rock and tailings mineralogy were determined using X-ray diffraction (XRD). Data were collected with a PANanalytical X'Pert PRO MPD X-ray diffractometer at the Centres Cientifics i Tecnològics de la Universitat de Barcelona (CCiT-UB) (Barcelona, Spain). Identification and semi-quantitative Rietveld evaluation of phases were made using the software X'Pert HighScore ${ }^{\circledR}$ (Version 2.0.1, PANanalytical, Almelo, The Netherlands). 
Thin and thick sections were prepared from the rock fragments of the ores to determine the mineralogy and textures. Mineralogical characterization was carried out using optical microscopy under reflected and transmitted light and scanning electron microscopy (SEM) with energy-dispersive spectral analysis used in the back-scattered electron mode (BSE). Analyses were carried out with a Hitachi TM-1000 tabletop microscope and an A JEOL Scanning electron microscope at the Centres Científics I Tecnològics de la Universitat de Barcelona (CCiT-UB). The operation conditions were a 20 $\mathrm{kV}$ acceleration voltage and a beam current of $20 \mathrm{nA}$.

Mineral chemistry of gold-bearing minerals and pyrite was quantitatively determined using a CAMECA SX-50 and a JEOL JXA-8230 electron microprobe at the CCiT-UB. The conditions of analysis were $25 \mathrm{kV}, 20 \mathrm{nA}$, a beam diameter of $1 \mu \mathrm{m}$, and a counting time of $10 \mathrm{~s}$. Natural and synthetic standards were used for external calibration.

To determine the gold grade, samples were ground and quartered until reaching the required size and quantity for the analyses. In the sampling of ROM and tailings, the size of samples was selected according to the Theory of Sampling [47]. In the veins from the underground mines, the possibility to obtain a large sample was limited. Samples were analysed in the ACTLABS and ALS laboratories, where the AU-AA25 and AU-GRA21 were used. Analyses of other elements were carried out in selected samples using Inductive Coupled Mass Spectrometry (ICP-MS).

The particle size distribution of the tailing samples was obtained using a Coulter Electronics LS230.

\section{Results}

\subsection{Host Vein Mineralogy}

Determination of the nature of the minerals that constitute the host rocks of the gold-bearing veins is important because they have an effect on the grinding characteristics, are necessary to define the effectiveness of cyanidation [26], and have to be quantified to predict the possible generation of acid mine drainage produced during the mining activities. In the Nazca-Ocoña belt, gold-bearing veins are filled with quartz and minor amounts of calcite appear only in some of them. These veins are hosted in igneous rocks, which mainly provide feldspars, muscovite, biotite, amphiboles, and chlorite. In veins from Cháparra, San Luis, and Santa Filomena, accompanying quartz XRDs show the occurrence of abundant hematite and goethite, with variable amounts of jarosite and gypsum.

The local hydrothermal alteration in the surroundings of the veins reduces the resistance of these host rocks, which facilitates the grinding processes. In addition, the presence of feldspars, amphiboles, and micas is beneficial to prevent the formation of acid mine drainage. However, this problem should be taken into account in sites where jarosite occurs.

\subsection{Gold Mineralogy}

In the deposits of the Nazca-Ocoña belt, gold occurs as native grains, electrum, and, in minor amounts, as tellurides. Visible gold is relatively abundant in Cháparra and Santa Filomena. The abundance of tellurides varies, being most abundant in San Luis.

In Misky and San Cristóbal, ore mineralogy is rich in sulfides, pyrite being the most abundant, followed by chalcopyrite. Other sulfides in significant amounts are sphalerite, galena, chalcocite and arsenopyrite; gold is abundant as electrum and in the native form. Native gold commonly appears as grains of less than $100 \mu \mathrm{m}$ included in pyrite, whereas electrum usually occurs filling fractures produced in the pyrite crystals and can be accompanied by native bismuth and other Bi-rich minerals (Figure 6). Pyrite forms coarse-grained, euhedral crystals, up to $2 \mathrm{~mm}$ in size and, in addition to gold, abundant inclusions of other sulfides, manly galena and chalcopyrite, can be present. Microprobe analyses of pyrite indicated that it has a low Au content, but this content can sporadically reach up to $0.61 \mathrm{wt}$. \% Au (Table 2). These anomalously high Au contents are accompanied by high contents of Ag and could be attributed to the presence of sub-microscopic gold or electrum. 

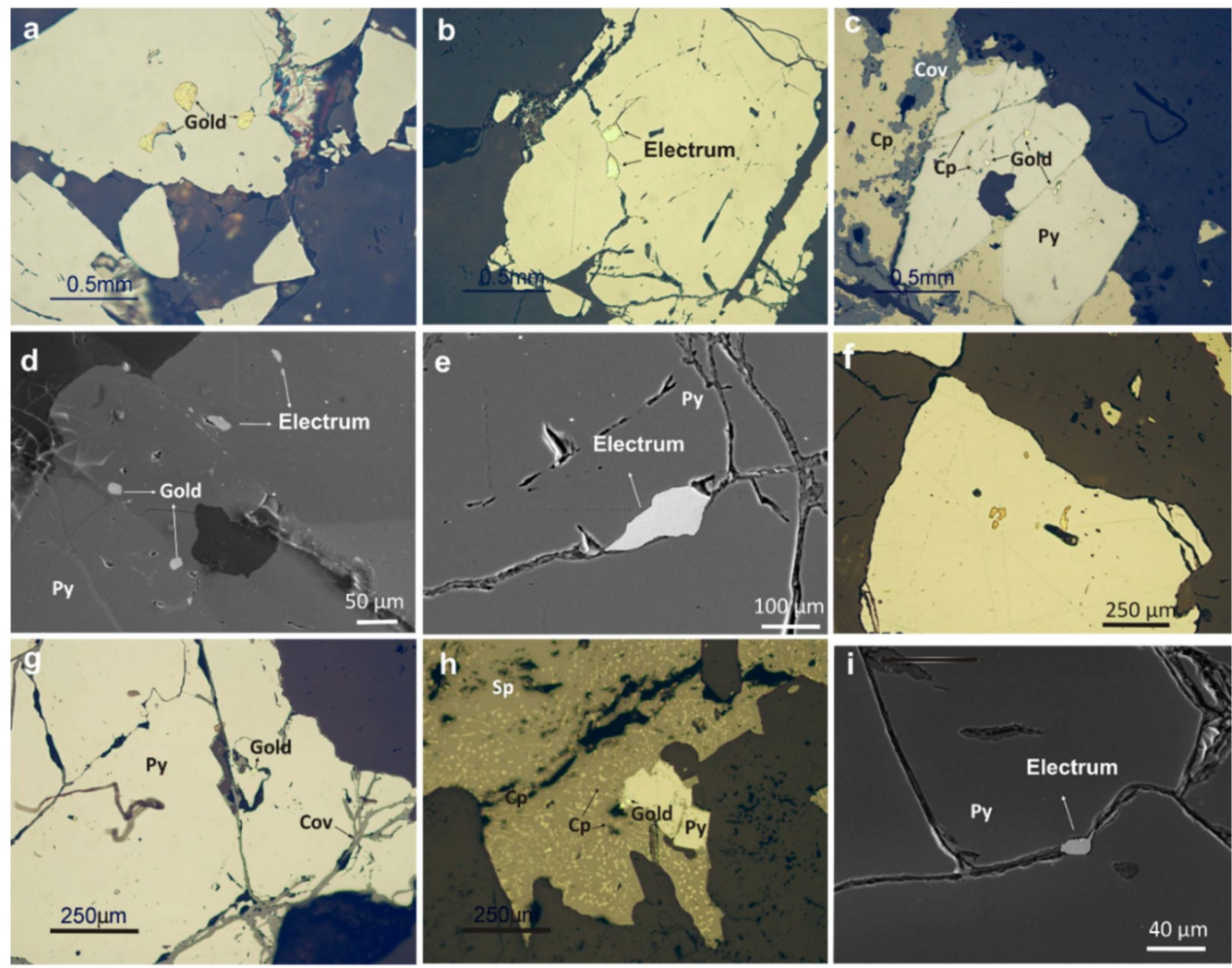

Figure 6. Images of gold mineralization. Misky, (a) native gold encapsulated in pyrite, (b) electrum following fractures, (c) pyrite with inclusions of native gold and chalcopyrite; chalcopyrite crystals are being replaced by covellite, (d) SEM images of native gold and electrum, (e) electrum as a fracture filling, (g-i) San Crstóbal, (f) EDS spectrum of electrum from image e, (g-i) gold encapsulated in pyrite associated with other sulfides, (i) Electrum in a pyrite fracture. Py, pyrite; $\mathrm{Cp}$, chalcopyrite; Cov, covellite; Sp, sphalerite.

Table 2. Microprobe analyses of representative samples of pyrite and tetrahedrite from Misky (Mk), San Cristóbal (SC) and Cháparra (Ch).

\begin{tabular}{cccccccccccc}
\hline & \multicolumn{1}{c}{ Pyrite } & \multicolumn{3}{c}{ Tetrahedrite } \\
\hline wt. \% & $\mathbf{M k 1 7}$ & $\mathbf{M k 1 4 a}$ & $\mathbf{M k 1 4 b}$ & $\mathbf{M k 1 0 6}$ & $\mathbf{S C 1}$ & SC78a & SC78b & SC68 & Ch1 & Ch4a & Ch4b \\
\hline $\mathrm{S}$ & 53.74 & 54.21 & 53.94 & 53.80 & 53.04 & 53.57 & 53.51 & 53.58 & 54.16 & 29.79 & 24.3 \\
$\mathrm{Fe}$ & 45.80 & 45.97 & 45.08 & 46.57 & 45.22 & 45.41 & 45.62 & 45.99 & 45.62 & 15.44 & 6.97 \\
$\mathrm{Cu}$ & 0.00 & 0.00 & 0.00 & 0.00 & 0.00 & 0.00 & 0.00 & 0.00 & 0.03 & 32.35 & 38.23 \\
$\mathrm{Zn}$ & - & - & - & 0.10 & - & - & - & - & - & 0.16 & 0.36 \\
$\mathrm{Te}$ & 0.00 & 0.00 & 0.00 & 0.00 & 0.04 & 0.00 & 0.00 & 0.02 & 0.00 & - & - \\
$\mathrm{Se}$ & 0.01 & 0.03 & 0.00 & 0.00 & 0.00 & 0.02 & 0.02 & 0.00 & 0.09 & 0.00 & 0.00 \\
$\mathrm{Ag}$ & 0.00 & 0.00 & 0.21 & 0.05 & 0.00 & 0.00 & 0.08 & 0.13 & 0.05 & 0.19 & 0.35 \\
$\mathrm{Au}$ & 0.00 & 0.10 & 0.58 & 0.61 & 0.04 & 0.05 & 0.00 & 0.21 & 0.00 & 0.00 & 0.58 \\
$\mathrm{As}$ & - & - & - & 0.00 & - & - & - & - & 0.01 & 0.00 & 0.32 \\
$\mathrm{Sb}$ & 0.01 & 0.00 & 0.01 & 0.08 & 0.00 & 0.02 & 0.00 & 0.00 & 0.02 & 13.77 & 20.03 \\
$\mathrm{~Pb}$ & 0.09 & 0.15 & 0.11 & 0.13 & 0.37 & 0.17 & 0.11 & 0.10 & 0.05 & 0.02 & 0.10 \\
$\mathrm{Total}$ & 99.65 & 100.46 & 99.93 & 99.40 & 101.48 & 99.25 & 99.34 & 100.02 & 100.00 & 99.02 & 97.01 \\
\hline
\end{tabular}

Gold mineralisation at Cháparra is characterized by the abundance of Fe oxides. Gold occurs in quartz veins that can be accompanied by high amounts of iron oxides and sulfides, mainly pyrite, pyrrhotite, chalcopyrite, galena, sphalerite, arsenopyrite and covellite. Rare earth element-rich minerals, such as monazite, also occur in minor amounts. Covellite, tetrahedrite, garavellite, annivite, and native bismuth occur as replacements or filling fractures in the previously formed minerals. In this case, 
native gold is the most abundant gold-bearing mineral and can be included in quartz, pyrite, and covellite (Figure 7). Tellurides are not common but occur sporadically. Microprobe analyses of in pyrite usually Au contents are negligible; however, tetrahedrite can reach up to $0.33 \mathrm{wt}$ \% Au (Table 2).
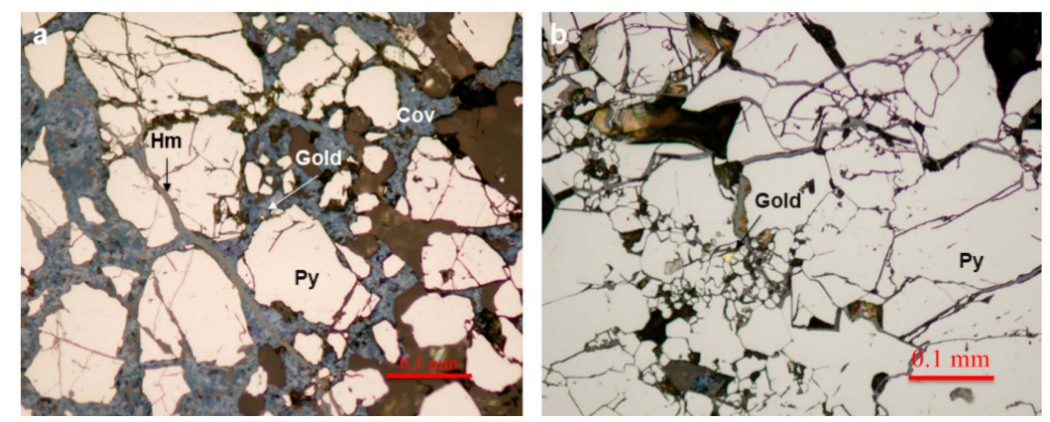

Figure 7. Gold mineralization from Cháparra. (a) Included in covellite, (b) included in pyrite.

In San Luis and Santa Filomena, gold occurs mainly as native gold grains, and electrum is less abundant than in Misky. Both occur as grains and filling fractures in pyrite, hematite and quartz (Figure $8 \mathrm{a}-\mathrm{c}$ ). In addition, tellurides are common in some areas of the San Luis mine. Tellurides occur filling voids or in trails into pyrite (Figure $8 \mathrm{~d}-\mathrm{g}$ ). The most common association of the tellurium with gold is calaverite $\left(\mathrm{AuTe}_{2}\right)$, but gold and tellurium from San Luis are also found in other minerals, as $\mathrm{Au}-\mathrm{Ag}$ tellurides, such as silvanite $\left((\mathrm{Ag}, \mathrm{Au})_{2} \mathrm{Te}_{4}\right)$, and Petzite $\left.\left(\mathrm{Ag}_{3} \mathrm{AuTe}\right)_{2}\right) \mathrm{Bi}, \mathrm{Pb}$, and $\mathrm{Ag}$ tellurides such as altaite $(\mathrm{PbTe})$ (Figure $8 \mathrm{~h})$, kawazulite $\left(\mathrm{Bi}_{2}(\mathrm{Te}, \mathrm{Se}, \mathrm{S})_{3}\right)$ (Figure $\left.8 \mathrm{i}\right)$, rucklidgeite $\left((\mathrm{Bi}, \mathrm{Pb})_{3} \mathrm{Te}_{4}\right)$, and hessite $\left(\mathrm{Ag}_{2} \mathrm{Te}\right)$ also occur.
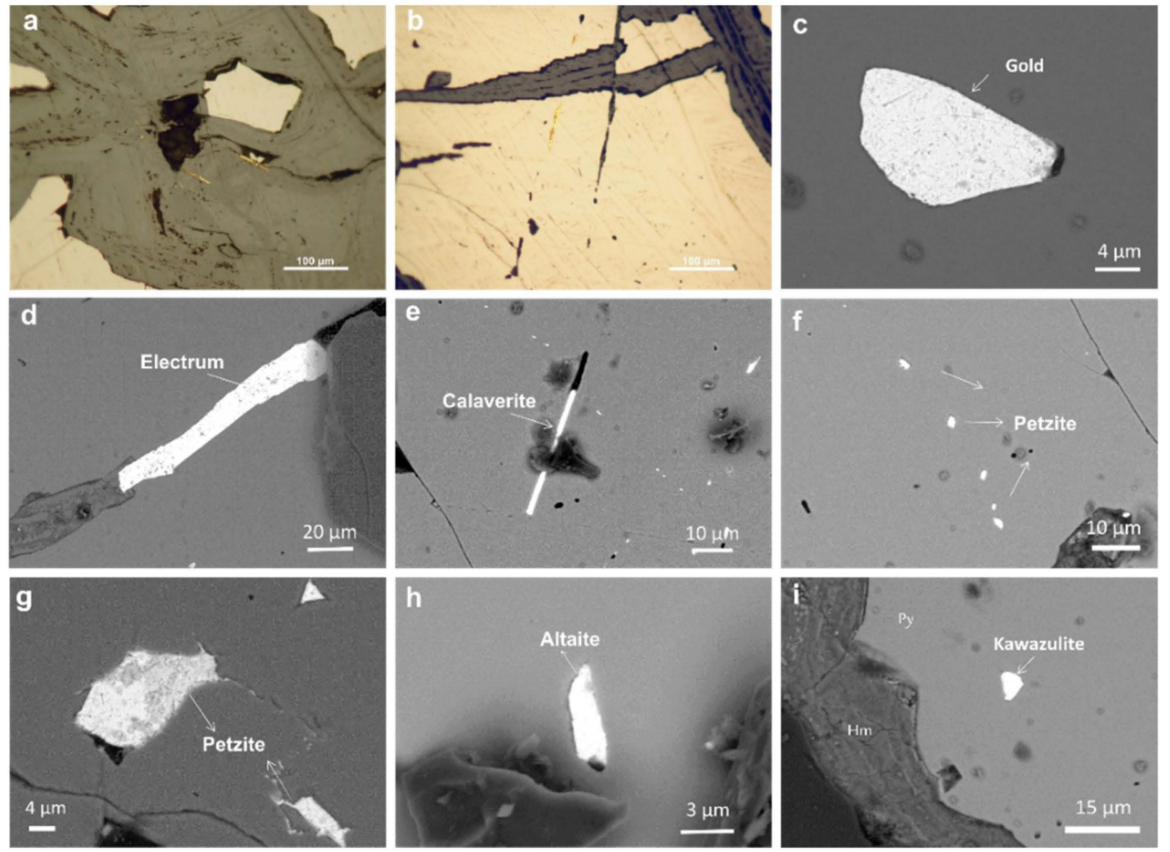

Figure 8. Microscopic images of gold from San Luis. (a) Optical microscope image of gold hosted in hematite; (b) optical microscope image of gold hosted in quartz; (c-i) scanning electron microscopy (SEM) images of Au and Te minerals hosted in pyrite.

In Santa Filomena, chalcopyrite and pyrite are locally abundant but gold is most commonly present enclosed in quartz associated with hematite. There are several generations of quartz, but only this contains gold (Figure 9). In the same vein, the gold grade varies with depth. In the gallery of the exploitation, the Escorpión vein has $63 \mathrm{~g} / \mathrm{t}$, whereas the outcropping vein has $1.2 \mathrm{~g} / \mathrm{t}$. Here, Te-rich minerals are rare. 

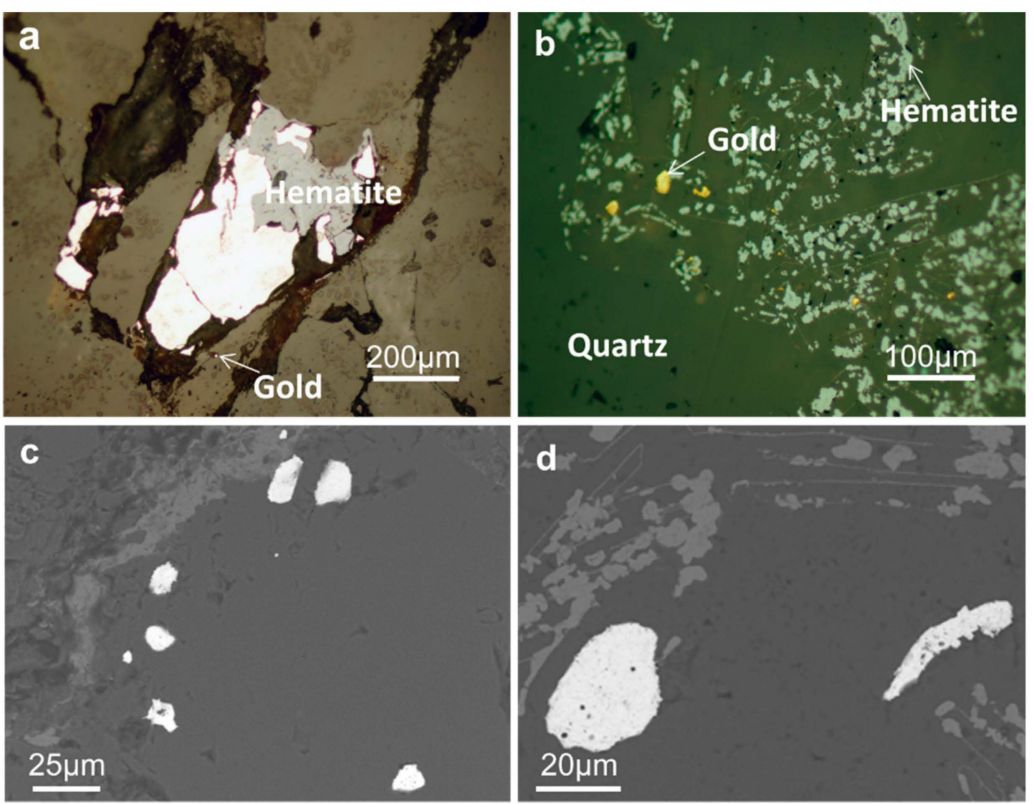

Figure 9. Microscopic images of gold from Santa Filonena. (a,b) Optical microscope image of gold hosted in quartz; (c,d) SEM images of gold minerals hosted in quartz.

The paragenetic observations indicate that in the vein mineralizations of the Nazca-Ocoña belt, gold is formed in two stages: (I) During the formation of the primary mineralization, which is responsible for gold encapsulated in pyrite, or in other sulfides and quartz, and (II) in a second stage of filling fractures of the minerals formed before, where the deposition of Ag-rich gold, electrum, gold-rich tellurides, bismuth-rich minerals, a late generation of galena and sulfosalts is produced. In Misky, the Au-Ag solid solution can reach up to $36 \mathrm{wt}$. \% $\mathrm{Ag}$, a the structural formula $\left(\mathrm{Ag}_{0.52} \mathrm{Au}_{0.48}\right)$, which corresponds to the kustelite member. In the other deposits analysed here, the Ag content is lower (Figure 10).

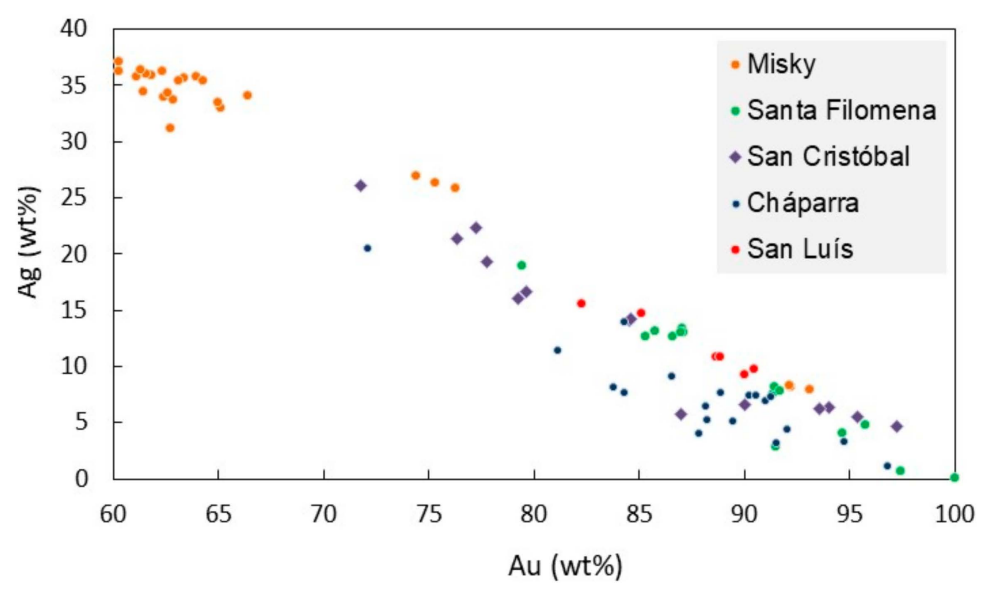

Figure 10. The Ag vs. Au content in gold-rich minerals from deposits in Mid-South Peru.

Finally, supergene alteration resulted in the oxidation of sulfides and formation of malachite, azurite, hematite, and goethite in all the deposits, and the oxidation of sulfates to form gypsum, jarosite, scorodite, and yodargirite in Cháparra. 


\subsection{Geochemistry of Ores}

Gold grade in the ROM ore varies widely. The most common values range between 20 and $60 \mathrm{~g} / \mathrm{t}$, but occasionally values of more than $100 \mathrm{~g} / \mathrm{t}$ were found. The highest contents were obtained in ores from Misky, with up to $134 \mathrm{~g} / \mathrm{t}$ Au (Table 3).

Table 3. The metal contents $(\mathrm{g} / \mathrm{t})$ of run of mine ore $(\mathrm{ROM})$ and ores from the studied areas. The average of eight analyses is presented for the Misky area.

\begin{tabular}{cccccccccc}
\hline Area & Location & Sample & Type & Au & Ag & Te & Zn & As & Hg \\
\hline Misky & Posta & MK-35 & ore & 134 & 45 & - & 98 & - & - \\
Misky & - & Average & ROM & 38 & 57 & - & 192 & - & - \\
San Cristóbal & - & SRC2 & ROM & 59 & 143 & - & 3560 & - & - \\
San Cristóbal & - & SRC3 & ROM & 33 & 117 & - & 5590 & 519 & 9 \\
San Cristóbal & - & QU2 & ROM & 28 & 138 & - & 4920 & 428 & 6 \\
Cháparra & San Martín & R-3a & Ore & 111 & 7 & - & 18 & 226 & $<1$ \\
Cháparra & Gallinazo & R-7b & Ore & 27 & 1 & - & 6 & 12 & $<1$ \\
Cháparra & Comuna & R-9a & Ore & 25 & 8 & - & 331 & 10,900 & $<1$ \\
Cháparra & Alto Perú & R-11 & Ore & 3 & 1 & - & 9 & 236 & $<1$ \\
Cháparra & 600-Aurex & R-12a & Ore & 18 & 0 & - & 2 & 126 & $<1$ \\
San Luis & Clider & SL-1 & Ore & 1 & - & - & - & - & - \\
San Luis & Main vein & SL-2m & Ore & 29 & - & - & - & - & - \\
San Luis & Main vein & SL-11 & Ore & 60 & - & 80 & - & - & - \\
Santa Filomena & Anampa & FDM-3 & ore & 23 & - & 10 & - & - & - \\
\hline
\end{tabular}

Ag contents are relatively high in Misky and San Cristóbal. A total of 20 ores obtained in the underground mines before any manual selection to obtain the ROM ore from the Misky area yield an average grade content of $14 \mathrm{~g} / \mathrm{t} \mathrm{Au}, 22.6 \mathrm{~g} / \mathrm{t} \mathrm{Ag}, 607 \mathrm{~g} / \mathrm{t} \mathrm{Cu}, 406 \mathrm{~g} / \mathrm{t} \mathrm{Pb}$, and $92 \mathrm{~g} / \mathrm{t} \mathrm{Zn}$. In San Cristóbal, the Au content ranges from 28 to $59 \mathrm{~g} / \mathrm{t}$ and the average grade of three samples was higher than $1 \mathrm{wt}$. $\% \mathrm{Cu}$, and more than $0.5 \mathrm{wt}$. \% Pb. In Cháparra, the gold content from the ROM ore ranges from $1 \mathrm{~g} / \mathrm{t}$ to more than $30 \mathrm{~g} / \mathrm{t}$, and the most common values are between 25 and $30 \mathrm{~g} / \mathrm{t}$. The Ag content is low, up to $7.7 \mathrm{~g} / \mathrm{t}$. The $\mathrm{Pb}$ contents are usually low, although they can reach up to more than $0.2 \mathrm{wt}$. \%. The content of As is highly variable. In Chaparra, As can reach up to more than $1 \mathrm{wt}$. \% The content of $\mathrm{Hg}$ is low in all cases, with less than $1 \mathrm{~g} / \mathrm{t} \mathrm{Hg}$.

In San Luis, the mined veins show high variability in the Au content, between 1 and $60 \mathrm{~g} / \mathrm{t}$. The Te content can reach up to $80 \mathrm{~g} / \mathrm{t}$, whereas in Santa Filomena, only $10 \mathrm{~g} / \mathrm{t}$ was obtained; this is in agreement with the high telluride minerals found in the SEM observations.

\subsection{Tailings}

The particle size distribution of the ground material from tailings is similar in all the areas (Figure 11). Average particle size is between 20 and $40 \mu \mathrm{m}$, the $\mathrm{D}_{80}$ being between 80 and $150 \mu \mathrm{m}$. The coarsest material corresponds to the quimbalete product from San Cristobal and, in the other areas material from quimbaletes and from ball mills has similar particle sizes. 


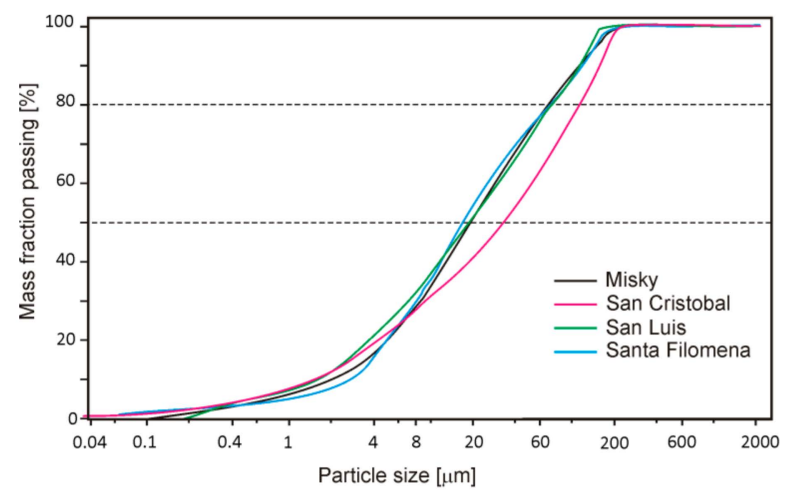

Figure 11. The particle size distribution of tailings from the studied area.

In the tailings, the Au content varies according to the used method for gold recovery. In tailings resulted from amalgamation, this content is always in remarkable amounts with respect to the common values of the ores; in the case of tailings from Cháparra, the Au content ranges from 5 to $34 \mathrm{~g} / \mathrm{t}$. In San Cristóbal, the Au content of tailings from the amalgamation process show high contents in $\mathrm{Au}$, As and $\mathrm{Hg}$. After cyanidation, these tailings lost most of the Au but also half of the As and $\mathrm{Hg}$ contents.

In other sites, such as San Luis and Santa Filomena, miners used amalgamation in the past but nowadays, they only use the cyanidation method for gold recovery. To assess the recovery performance, a sample of the cyanidation tailing from each location was analysed. In San Luis, the ROM came from a vein, with gold grades exceeding $20 \mathrm{ppm}$ and the tailing material yields $1.78 \mathrm{~g} / \mathrm{t} \mathrm{Au}$, which indicates that most of the gold was already in the cyanided solution. This interpretation is corroborated by the results of the stored tails, which show a gold content of $1.25 \mathrm{~g} / \mathrm{t}$. These results are indicative of relatively correct processing, despite it being capable of being improved. In contrast, the analysis of ancient tailing that came from the amalgamation process shows high gold contents, up to $52 \mathrm{ppm}$ (Table 4), which indicate that the recovery system was inefficient.

Table 4. The metal contents $(\mathrm{g} / \mathrm{t})$ of processed ores, after amalgamation $(\mathrm{A})$ and after cyanidation $(\mathrm{C})$.

\begin{tabular}{cccccccc}
\hline Area & Sample & Process & Au & Ag & Zn & As & Hg \\
\hline San Cristóbal & SRC1 & A & 19 & 176 & 2.620 & 434 & 917 \\
San Cristóbal & SRC4 & A & 56 & 207 & $>10.000$ & 973 & 902 \\
San Cristóbal & QU1 & C & 11 & 175 & 8.640 & 472 & 228 \\
San Cristóbal & QU3 & C & 1 & 64 & 3.110 & 291 & 589 \\
\hline Cháparra & Ch-1 & A & 27 & 4 & 11 & 404 & 68 \\
Cháparra & Ch-2 & A & 35 & 11 & 1.780 & 727 & 49 \\
Cháparra & Ch-3 & A & 8 & 2 & 11 & 411 & 117 \\
Cháparra & Ch-4 & A & 16 & 4 & 1.510 & 370 & 324 \\
Cháparra & Ch-5 & A & 5 & 7 & 19 & 209 & 252 \\
\hline San Luis & L-6 & A & 52 & 10 & 14 & 48 & $<1$ \\
San Luis & L-7 & A & 40 & 8 & 11 & 44 & $<1$ \\
San Luis & L-2 & A & 35 & 13 & & & \\
San Luis & PLO4 & C & 1 & & & & \\
Santa Filomena & SFE & C & 16 & & & &
\end{tabular}

In Santa Filomena, the cyanidation tailings still contain significant amounts of gold. 


\section{Discussion}

\subsection{Gold Recovery}

\subsubsection{Processing by Amalgamation}

The present study confirms that the recovery of gold through amalgamation is very inefficient. Usually, with this method, the efficiency of gold recovery is less than $30 \%$ [10]. However, this is an expected situation since gold must have been liberated from the matrix in which it has been encapsulated [48-50].

The poor gold recovery using amalgamation produces high economic losses to the artisanal miners. A growing number of miners know these losses and, for that reason, they frequently process the amalgamated tailings by cyanidation [51] and every day abandon the amalgamation method more, frequently turning to the use of cyanidation. The increase in the price of mercury [52] also probably contributes to this change.

On the other hand, these tailings contain other metals that could be of economic importance or in any case, their amount could be significant with regard to environmental pollution, such as $\mathrm{Cd}, \mathrm{Pb}, \mathrm{Zn}$, and As, among others. In the same way, the concentration of $\mathrm{Hg}$ in these tails due to amalgamation is considerably high.

In San Cristóbal, the low recovery during amalgamation can be observed by comparison of the grade of gold in the ROM ore and the amalgamated tailing (Table 4). Even after cyanidation, the gold losses are considerably high and the Au content of these tailings is high enough to be of economic interest. In addition, tailings are enriched with contaminants, such as $\mathrm{Hg}$ and As (Table 4). The Hg content in tailings after amalgamation is reduced by half after cyanidation, suggesting that most $\mathrm{Hg}$ was released to the cyanide solution or to the atmosphere. A similar decrease of almost $50 \%$ in the concentration of mercury in the cyanidation tailings relative to the input amalgamation tailings was found in the Lombok Island area of Indonesia [51].

\subsubsection{Processing of Refractory Gold Ores}

Gold ores that require additional treatment to the conventional physical processing for recovery are called refractory gold ores. In general, ores with gold included in sulfides, sulfosalts, and silicates are refractory. Then, gold from all the studied mine sites can be considered as refractory.

The amalgamation process takes place only when gold is liberated from the matrix by being in direct contact with mercury. As gold is usually present in particles of a few microns in size, after grinding, a significant amount of this is not liberated and cannot form the amalgam with mercury and, therefore, this will remain in the tailings.

In the case of the use of cyanidation, the low recovery obtained by the conventional process is due to two main reasons. Firstly, in high-refractory ores, the gold can be locked up in the mineral matrix so that leaching reagents are unable to reach it. Secondly, in complex ores, reactive minerals in the ore can rapidly consume the leaching reagents and there may be insufficient cyanide and/or oxygen in the pulp to leach the gold [53]. In both cases, a portion of gold will remain in the tails.

Host minerals of refractory gold must be dissolved to liberate gold [54]. Refractory ores require fine milling and an additional pre-treatment step, such as toasting and pressure oxidation, to make gold minerals susceptible to extraction. For this reason, oxidative pre-treatments are generally carried out to improve the recovery of gold.

For gold ores encapsulated in sulfides, first, the sulfide mineral must be destroyed, totally or partly, to ensure that the cyanide solution reaches the gold. An important aspect is the size of particles to be treated. One proposed solution is an ultrafine grinding process of the ore, e.g., González-Anaya et al. [55] use a ground ore with $80 \%$ of particles $\left(P_{80}\right)$ of less than $46 \mu \mathrm{m}$. Ultrafine milling produces extremely fine particles of 10 to $15 \mu \mathrm{m}$, that maximize the mineral liberation and the interaction between the surface of minerals and the cyanide solution, as well as the mechanical 
activation of the surface, with a subsequent increment in the leaching rate. However, this action can consume significant proportions of reagents and reduce the level of dissolved oxygen attainable [56]. Therefore, it is a viable and effective technology, but it is still not ideal. In addition, grinding consumes a large amount of energy and it greatly increases the production costs.

In the case of gold encapsulated in quartz, a preliminary treatment with HF was proposed to dissolve quartz, in addition to the use of oxalic acid to destroy hematite [57].

In San Cristóbal and Santa Filomena, the low recovery using cyanidation could be due to the fact that gold is enclosed in pyrite and quartz and with no preliminary treatment applied. In San Luis, the complex mineralogy of gold has to be taken into account in addition to the refractory behaviour of the ore. Gold tellurides do not dissolve rapidly in conventional leaching solutions using alkaline cyanide [58]. Therefore, alternative treatments must be applied to break the structure of the gold tellurides and release free gold. Gold tellurides react with cyanide and a tellurous acid is deposited on the surface of the mineral, which is only soluble in acid or at $\mathrm{pH}$ values higher than 12 [54,57]. In San Luis, the ground ore is mixed with cement during cyanidation, increasing the $\mathrm{pH}$ of the solution up to about 13. This $\mathrm{pH}$ facilitates the dissolution of tellurides. The additional treatment to liberate the gold grains and to obtain a concentrate by cyanidation was effective and, in San Luis, a high gold recovery was obtained. However, the $1 \mathrm{~g} / \mathrm{t}$ of gold that remains in the tailings is of economic interest.

Cyanidation shows better results than amalgamation, as was demonstrated in other cases [59]. However, in the case of Santa Filomena, after cyanidation, the tailing was considerably rich in $\mathrm{Au}, 16$ $\mathrm{g} / \mathrm{t} \mathrm{Au}$. The mineral association of gold limited the effectiveness of cyanidation [60-62]. In this place, only ore and cyanide were introduced in the cyanidation ponds without the addition of cement and the $\mathrm{pH}$ of the solution was close to 7. Additionally, the presence of a high content of $\mathrm{Cu}$-rich minerals must be taken into account, because $\mathrm{Cu}$ forms complexes with cyanide and, then, more cyanide must be added in the solution; the most effective $\mathrm{Cu} /$ cyanide ratio is about 5:1 [60]. Moreover, the addition of cement prevents acid generation and As leaching from the tailings [63].

\subsection{Clean Processing Methods for Gold Artisanal Mining}

It is necessary to adopt methods of mercury-free processing [23]. Cyanidation is the most adopted process to replace amalgamation. However, it is not the most environmentally friendly technique, especially if it is carried out with tailings that have been processed through amalgamation [64]. Cyanide is highly toxic both to humans and to the environment. However, there is no agreement among researchers regarding the convenience of adopting the use of cyanide for the recovery of gold. According to Reference [12], this use represents a minimum hazard if it is done correctly, its use is controlled in all stages of the process, and the residual cyanide contained in the tailings is destroyed. Therefore, other suitable methods must be found for each type of ore that will allow efficient gold processing, both from an environmental and economic point of view. Many alternative techniques have been proposed as clean methods of gold recovery available to the artisanal miners $[65,66]$.

Gravity concentration provides clean methods of gold recovery that is used in many artisanal gold operations; however, the efficiency of these methods is reduced to recover the fine gold particles and, frequently, miners complement these concentration methods with amalgamation. Thus, mercury consumption is reduced but not totally eliminated [15].

One of the methods used by the miners is gold recovery using borax [22,67-70]. The health risks associated with the use of borax for gold recovery are very limited; only irritation to the eyes, throat, nose, and skin is caused by the dust produced [71].

Gold phytoextraction was proposed for tailings [72,73] and low-grade gold ores [74]. It was investigated for gold recovery in amalgamated tailings from the artisanal mining activities of Indonesia [51]. The use of a suitable plant not only provides a method to recover gold and other metals contained in them, but also to clean the tail of mercury [75-77]. The use of Manihot esculenta Crant (cassava) and Brassica juncea plants for phytoextraction from tailings can recover gold, and also $\mathrm{Hg}$, making it a good system for the treatment of amalgamated gold tailings [74,78]. 
The use of eutectic solvent ionic liquids to dissolve gold was proposed as a non-pollutant technique that, in addition to gold, can selectively recover other metals, such as tellurium and silver $[79,80]$. The ionic liquids most suited have been investigated [81], but specific research should be conducted to the application of this technique in the different gold ores.

Other proposed techniques for gold recovery in artisanal mining were direct smelting [81], centrifugation, magnetic removal of gangue material [64], and chlorination $[82,83]$. The use of chlorine solution to extract metals is used by several mining companies and has the advantage that other metals, such as Ag and $\mathrm{Cu}$ can also be recovered [84].

\subsection{Final Recommendations}

Prior to any treatment for gold recovery, the mineralogy of gold ores must be known and, based on this, the appropriate recovery procedure must be designed. It is highly important to optimize the recovery and to minimize environmental pollution.

Miners should not apply the cyanidation method in tailings containing materials that have previously been amalgamated with mercury, as was indicated in the action plans drafted by the Minamata convention [85].

Official entities and NGOs should work on the development of a guide for artisanal miners to help them to choose the right processing flux diagram according to the characteristics of the materials to be treated.

Finally, more research should be done on environmentally friendly techniques to improve them and to determine in which situations they can be applied.

\section{Conclusions}

In the Nazca-Ocoña gold belt, gold occurs mostly in quartz veins as native grains are encapsulated in pyrite and in minor amounts in other sulfides, hematite, and quartz. Electrum and tellurides occur mainly filling spaces in voids and fractures located predominantly in pyrite.

In the ASM from the Mid-South Peru gold processing is carried out by amalgamation with mercury and by cyanidation. Gold from this area is not liberated but hosted by sulfides and, in minor amounts, by quartz and hematite. Then, it can be considered as refractory.

The determination of the gold grade in the ROM ore and in the residual tailings indicates the existence of low gold recovery during processing with mercury in the mills. The tailings still contain high contents of gold, showing that the amalgamation method is a low-efficient technique.

In some cases, low gold recovery was also determined for ores processed by cyanidation. When cement was added to the cyanide solution, the recovery was remarkably high.

When the cyanidation process is carried out in tailings previously treated with mercury, part of the mercury retained in them is released to the atmosphere or to the cyanidation fluids. This pollution requires the use of alternative methods of gold recovery to achieve sustainable gold mining activity.

Author Contributions: P.A. wrote the paper; H.A. studied the San Cristóbal area; T.Y. was responsible of the study in the San Luis and Santa Filomena areas. L.H. participated in the field work of the San Luis area; S.P. was responsible of the Misky area, J.Y was responsible of the study in Cháparra. M.B. assisted with the planning of the field work. M.G.-V. assisted with the mineralogical analyses. All authors contributed to data interpretation and discussion.

Funding: This research was funded by the Centre de Cooperació al desenvolupament de la Universitat Politècnica de Cataluya (CCD) during campaigns from 2010 to 2017. The research is supported by the SGR-198 and SGR-707 of the Generalitat de Catalunya.

Acknowledgments: Alianza para la Mineria Responsible (ARM), especially Natália González Párias and Javier Yrigoyen, Red Social (Olinda Orozco) and SONAMIPE (Manuel Reinoso) and members of the ONG Mineria per al Desenolupament assisted in the field work. The comments of three anonimous reviewers contributed to improve the manuscript.

Conflicts of Interest: The authors declare no conflict of interest. 


\section{References}

1. Veiga, M.M.; Baker, R. Protocols for Environmental and Health Assessment of Mercury Released by Artisanal and Small-Scale Gold Miners; United Nations: New York, NY, USA, 2004; p. 289.

2. Seccatore, J.; Veiga, M.; Origliasso, C.; Marin, T.; De Tomi, G. An estimation of the artisanal small-scale production of gold in the world. Sci. Total Environ. 2014, 496, 662-667. [CrossRef] [PubMed]

3. IGF (Intergovernmental Forum on Mining, Minerals, Metals and Sustainable Development). Global Trends in Artisanal and Small-Scale Mining (ASM): A Review of Key Numbers and Issues; The International Institute for Sustainable Development: Winnipeg, MB, Canada, 2017.

4. UNIDO (United Nations Industrial Development Organisation). Global Impacts of Mercury Supply and Demand in Small-Scale Gold Mining: Global Mercury Project; UNEP: Nairobi, Kenya, 2007.

5. Corbett, T.; O'Faircheallaigh, C.; Regan, A. 'Designated areas' and the regulation of artisanal and small-scale mining. Land Use Policy 2017, 68, 393-401. [CrossRef]

6. World Bank Group. Economy Profile of Peru. Doing Business 2019; World Bank: Washington, DC, USA, 2018; Available online: https://openknowledge.worldbank.org/handle/10986/30811 (accessed on 20 February 2019).

7. Cortés-McPherson, D. Expansion of small-scale gold mining in Madre de Dios: "capital interests" and the emergence of a new elite of entrepreneurs in the Peruvian Amazon. Extr. Ind. Soc. 2019. [CrossRef]

8. Valdivia, S.M.; Ugaya, C.M. Life Cycle Inventories of Gold Artisanal and Small-Scale Mining Activities in Peru: Toward Indicators for South America. J. Ind. Ecol. 2011, 15, 922-936. [CrossRef]

9. Hilson, G.; Maconachie, R. Formalising artisanal and small-scale mining: Insights, contestations and clarifications. Area 2017, 49, 443-451. [CrossRef]

10. UNEP. Analysis of Formalization Approaches in the Artisanal and Small-Scale Gold Mining Sector Based on Experiences in Ecuador, Mongolia, Peru, Tanzania and Uganda. Peru Case Study; Report; UNEP: Nairobi, Kenya, 2012; 33p.

11. Veiga, M.M.; Angeloci, G.; Niquen, W.; Seccatore, J. Reducing mercury pollution by training Peruvian artisanal gold miners. J. Clean. Prod. 2015, 94, 268-277. [CrossRef]

12. Sousa, R.N.; Veiga, M.M.; Klein, B.; Telmer, K.; Gunson, A.J.; Bernaudat, L. Strategies for reducing the environmental impact of reprocessing mercury-contaminated tailings in the artisanal and small-scale gold mining sector: Insights from Tapajos River Basin, Brazil. J. Clean. Prod. 2010, 18, 1757-1766. [CrossRef]

13. Stocklin-Weinberg, R.; Veiga, M.M.; Marshall, B.G. Training artisanal miners: A proposed framework with performance evaluation indicators. Sci. Total Environ. 2019, 660, 1533-1541. [CrossRef]

14. Keovilignavong, O. Mining governance dilemma and impacts: A case of gold mining in Phu-Hae, Lao PDR. Resour. Policy 2019, 61, 141-150. [CrossRef]

15. Hinton, J.J.; Veiga, M.M.; Veiga, A.T.C. Clean artisanal gold mining: A utopian approach? J. Clean. Prod. 2003, 11, 99-115. [CrossRef]

16. Labonne, B. Who is afraid of artisanal and small-scale mining (ASM)? Extr. Ind. Soc. 2014, 1, 121-123. [CrossRef]

17. Laurence, D. Establishing a sustainable mining operation: An overview. J. Clean. Prod. 2011, 19, $278-284$. [CrossRef]

18. McMahon, G.; Evia, J.L.; Pascó-Font, A.; Sánchez, J.M. An Environmental Study of Artisanal, Small, and Medium Mining in Bolivia, Chile, and Peru; Technical Paper No. 429; The World Bank: Washington, DC, USA, 1999.

19. Loredo, J.; Soto, J.; Ordonez, A.; Alvarez, R. Mercury and arsenic pollution associated to artisanal gold mining in Huanca (Ayacucho Department, Peru). Fresenius Environ. Bull. 2009, 18, 391-398.

20. Cordy, P.; Veiga, M.M.; Salih, I.; Al-Saadi, S.; Console, S.; Garcia, O.; Mesa, L.A.; Velásquez-López, P.C.; Roeser, M. Mercury contamination from artisanal gold mining in Antioquia, Colombia: The world's highest per capita mercury pollution. Sci. Total Environ. 2011, 410, 154-160. [CrossRef] [PubMed]

21. Gibb, H.; O'Leary, K.G. Mercury exposure and health impacts among individuals in the artisanal and small-scale gold mining community: A comprehensive review. Environ. Health Perspect. 2014, 122, 667-672. [CrossRef] [PubMed]

22. Zolnikov, T.R.; Ramírez Ortiz, D. A systematic review on the management and treatment of mercury in artisanal gold mining. Sci. Total Environ. 2018, 633, 816-824. [CrossRef] [PubMed]

23. Esdaile, L.; Chalker, J.M. The Mercury Problem in Artisanal and Small-Scale Gold Mining. Chem. Eur. J. 2018, 24, 6905-6916. [CrossRef] 
24. Seccatore, J.; de Tomi, G.; Veiga, M. Efficiency as a road to sustainability in small scale mining. Mater. Sci. Forum 2015, 805, 395-402. [CrossRef]

25. Kuramoto, J.R. Artisanal and Informal Mining in Peru; Report; International Institute for Environment and Development: Washington, DC, USA, 2001.

26. Harris, D.D. The Mineralogy of gold and its relevance to gold recoveries. Miner. Deposita 1990, 25, S3-S7. [CrossRef]

27. Goodall, W.R.; Scales, P.J.; Butcher, A.R. The use of QEMSCAN and diagnostic leaching in the characterisation of visible gold in complex ores. Miner. Eng. 2015, 18, 877-886. [CrossRef]

28. Chryssoulis, S.L.; McMullen, J. Mineralogical investigation of gold ores. Dev. Miner. Process. 2005, 15, $21-71$.

29. Gorain, B.K.; Kondos, P.D.; Lakshmanan, V.I. Innovations in gold and silver processing. In Innovative Process Development in Metallurgical Industry; Springer: Cham, Switzerland, 2016; pp. 393-428.

30. Sykora, S.; Cooke, D.R.; Meffre, S.; Stephanov, A.S.; Gardner, K.; Scott, R.; Selley, D.; Harris, A.C. Evolution of pyrite trace element compositions from porphyry-style and epithermal conditions at the Lihir gold deposit: Implications for ore genesis and mineral processing. Econ. Geol. 2018, 113, 193-208. [CrossRef]

31. Coetzee, L.L.; Theron, S.J.; Martin, G.J.; Van der Merwe, J.D.; Stanek, T.A. Modern gold deportments and its application to industry. Miner. Eng. 2011, 24, 565-575. [CrossRef]

32. Cook, N.J.; Chryssoulis, S.L. Concentrations of invisible gold in the common sulphides. Can. Miner. 1990, 28, 1-16.

33. Vaughan, J.P. The process mineralogy of gold: The classification of ore types. JOM 2004, 56, 46-48. [CrossRef]

34. Petruk, W. Applied Mineralogy in the Mining Industry; Elsevier: Amsterdam, The Netherlands, 2000.

35. Childs, J. From 'criminals of the earth' to 'stewards of the environment': The social and environmental justice of Fair Trade gold. Geoforum 2014, 57, 129-137. [CrossRef]

36. Fritz, M.M.; Maxson, P.A.; Baumgartner, R.J. The mercury supply chain, stakeholders and their responsibilities in the quest for mercury-free gold. Resour. Policy 2016, 50, 177-192. [CrossRef]

37. Cobbing, E.J.; Pitcher, W.S.; Taylor, W.P. Segments and super-units in the Coastal Batholith of Peru. The J. Geol. 1977, 85, 625-631. [CrossRef]

38. Cobbing, E.J. The segmented coastal Batholith of Peru: Its relationship to volcanicity and metallogenesis. Earth Sci. Rev. 1982, 18, 241-251. [CrossRef]

39. Vargas, A.R. Estudio geológico-minero de la faja aurífera Nazca-Ocoña; Technical Report; Ingemmet: Lima, Peru, 1978; p. 179.

40. Vidal, C.E. Metallogenesis associated with the Coastal Batholith of Peru: A review. In Magmatism at a plate edge. The Peruvian Andes; Blckie \& Son Ltd.: Glasgow, UK, 1985; pp. 243-249.

41. Steinmüller, K. Depósitos Metálicos en el Perú. Su Metalogénia, Sus Modelos, su Exploración y el Medio Ambiente; Ingemmet: Lima, Peru, 1999; p. 171.

42. Acosta, J.; Quispe, J.; Rivera, R.; Valencia, M.; Chirif, H.; Huanacuni, D.; Rodríguez, I.; Villarreal, E.; Paico, D.; Santisteban, A. Mapa Metalogenético del Oro en el Perú; INGEMET: Lima, Peru, 2010.

43. Sillitoe, R.H.; Thompson, J.F. Intrusion-Related Vein Gold Deposits: Types, Tectono-Magmatic Settings and Difficulties of Distinction from Orogenic Gold Deposits. Resour. Geol. 1998, 48, 237-250. [CrossRef]

44. Cardozo, M.; Cedillo, E. Geologic-metallogenetic evolution of the Peruvian Andes. In Stratabound ore Deposits in the Andes; Springer: Berlin/Heidelberg, Germany, 1990; pp. 37-60.

45. Acosta, J. Características metalogénicas de los yacimientos asociados a los arcos magmáticos mesozoicos y cenozoicos del sur del Perú (Latitudes $14^{\circ}-16^{\circ}$ S); INGEMET: Lima, Peru, Unpublished Technical Report; 2006.

46. Palacios, S.; Alfonso, P.; mata-Perelló, J.M. Caracterización del Yacimiento de Oro de Misky, Sur del Perú. Macla 2011, 15, 159-160.

47. Dominy, S.; O'Connor, L.; Glass, H.; Purevgerel, S.; Xie, Y. Towards Representative Metallurgical Sampling and Gold Recovery Testwork Programmes. Minerals 2018, 8, 193. [CrossRef]

48. Whitehouse, A.E.; Posey, H.H.; Gillis, T.D.; Long, M.B.; Mulyana, A.A.S. Mercury discharges from small scale gold mines in North Sulawesi, Indonesia: Managing a change from mercury to cyanide. In Proceedings of the 7th International Conference on Acid Rock Drainage (ICARD), St. Louis, MO, USA, 26-30 March 2006; Volume 26, pp. 2354-2368.

49. Hylander, L.D.; Plath, D.; Miranda, C.R.; Lücke, S.; Öhlander, J.; Rivera, A.T.F. Comparison of Different Gold Recovery Methods with Regard to Pollution Control and Efficiency. Clean Soil Air Water 2007, 35, 52-61. [CrossRef] 
50. Velásquez-López, P.C.; Veiga, M.M.; Klein, B.; Shandro, J.A.; Hall, K. Cyanidation of mercury-rich tailings in artisanal and small-scale gold mining: Identifying strategies to manage environmental risks in Southern Ecuador. J. Clean. Prod. 2011, 19, 1125-1133. [CrossRef]

51. Krisnayanti, B.D.; Anderson, C.W.; Utomo, W.H.; Feng, X.; Handayanto, E.; Mudarisna, N.; Ikram, H.; Khususiah. Assessment of environmental mercury discharge at a four-year-old artisanal gold mining area on Lombok Island, Indonesia. J. Environ. Monit. 2012, 14, 2598-2607. [CrossRef] [PubMed]

52. Veiga, M.M.; Angeloci, G.; Hitch, M.; Colón, P.; Velásquez-López, P.C. Processing centres in artisanal gold mining. J. Clean. Prod. 2014, 64, 535-544. [CrossRef]

53. La Brooy, S.R.; Linge, H.G.; Walker, G.S. Review of gold extraction from ores. Miner. Eng. 1994, 7, $1213-1241$. [CrossRef]

54. Kyle, J.H.; Breuer, P.L.; Bunney, K.G.; Pleysier, R. Review of trace toxic elements (Pb, Cd, Hg, As, Sb, Bi, Se, $\mathrm{Te}$ ) and their deportment in gold processing: Part II: Deportment in gold ore processing by cyanidation. Hydrometallurgy 2012, 111, 10-21. [CrossRef]

55. González-Anaya, J.A.; Nava-Alonso, F.; Pecina-Treviño, E.T. Gold recovery optimization of a refractory concentrate by ultrafine grinding-A laboratory study. Min. Metall. Explor. 2011, 28, 94-101. [CrossRef]

56. Dyer, L.G.; Sauber, M.; Dixon, D.G.; Asselin, E. On the refractory nature of precious metal tellurides. Hydrometallurgy 2017, 169, 488-495. [CrossRef]

57. Lorenzen, L. Some guidelines to the design of a diagnostic leaching experiment. Miner. Eng. 1995, 8, $247-256$. [CrossRef]

58. Zhang, J.; Zhang, Y.; Richmond, W.; Wang, H.P. Processing technologies for gold-telluride ores. Int. J. Min. Met. Mater. 2010, 17, 1-10. [CrossRef]

59. Jayasekera, S.; Jayasekera, I.M.; Ritchie, J. Avraamides. Prospects for the direct leaching of gold tellurides-Recent developments. In Proceedings of the World Gold '91, Cairns, Parkville, Australia, 21-25 April 1991; pp. 181-183.

60. Venter, D.; Chryssoulis, S.L.; Mulpeter, T. Using mineralogy to optimize gold recovery by direct cyanidation. JOM 2004, 56, 53-56. [CrossRef]

61. Azizi, A.; Petre, C.F.; Olsen, C.; Larachi, F. Electrochemical behavior of gold cyanidation in the presence of a sulphide-rich industrial ore versus its major constitutive sulphide minerals. Hydrometallurgy 2010, 101, 108-119. [CrossRef]

62. Kim, R.; Ghahreman, A. The effect of ore mineralogy on the electrochemical gold dissolution behavior in various cyanide and oxygen concentrations; Effect of sulfidic ores containing heavy metals. Hydrometallurgy 2019, 184, 75-87. [CrossRef]

63. Malloch, K.R.; Craw, D. Comparison of contrasting gold mine processing residues in a temperate rain forest, New Zealand. Appl. Geochem. 2017, 84, 61-75. [CrossRef]

64. Velásquez-López, P.C.; Veiga, M.M.; Hall, K. Mercury balance in amalgamation in artisanal and small-scale gold mining: Identifying strategies for reducing environmental pollution in Portovelo-Zaruma, Ecuador. J. Clean. Prod. 2010, 18, 226-232. [CrossRef]

65. Drace, K.; Kiefer, A.M.; Veiga, M.M.; Williams, M.K.; Ascari, B.; Knapper, K.A.; Logan, K.M.; Breslin, V.M.; Skidmore, A.; Bolt, D.A.; et al. Mercury-free, small-scale artisanal gold mining in Mozambique: Utilization of magnets to isolate gold at clean tech mine. J. Clean. Prod. 2012, 32, 88-95. [CrossRef]

66. Davies, G.R. A toxic free future: Is there a role for alternatives to mercury in small-scale gold mining? Futures 2014, 62, 113-119. [CrossRef]

67. Aylmore, M.G. Alternative lixiviants to cyanide for leaching gold ores. In Gold Ore Processing; Elsevier: Amsterdam, The Netherlands, 2016; pp. 447-484.

68. Appel, P.W.; Na-Oy, L. The borax method of gold extraction for small-scale miners. J. Health Pollut. 2012, 2, 5-10. [CrossRef]

69. Appel, P.W.U.; Na-Oy, L.D. Mercury-free gold extraction using borax for small-scale gold miners. J. Environ. Protect. 2014, 5, 493. [CrossRef]

70. Steckling, N.; Bose-O'Reilly, S.; Shoko, D.; Muschack, S.; Schierl, R. Testing local conditions for the introduction of a mercury-free gold extraction method using borax in Zimbabwe. J. Health Pollut. 2014, 4, 54-61. [CrossRef]

71. Riederer, A.; Caravanos, J. 1 BORAX-Summary of Health Risks Associated with Using Borax in Artisanal and Small-Scale Gold Mining; Blacksmith Institute: New York, NY, USA, 2013. 
72. Anderson, C.; Moreno, F.; Meech, J. A field demonstration of gold phytoextraction technology. Miner. Eng. 2005, 18, 385-392. [CrossRef]

73. Wilson-Corral, V.; Anderson, C.; Rodriguez-Lopez, M.; Arenas-Vargas, M.; Lopez-Perez, J. Phytoextraction of gold and copper from mine tailings with Helianthus annuus L. and Kalanchoe serrata L. Miner. Eng. 2011, 24, 1488-1494. [CrossRef]

74. Sheoran, V.; Sheoran, A.S.; Poonia, P. Phytomining of gold: A review. J. Geochem. Explor. 2013, 128, 42-50. [CrossRef]

75. Hidayati, N.; Juhaeti, T.; Syarif, F. Mercury and cyanide contaminations in gold mine environment and possible solution of cleaning up by using phytoextraction. HAYATI J. Biosci. 2009, 16, 88-94. [CrossRef]

76. Handayanto, E.; Muddarisna, N.; Krisnayanti, B.D. Induced phytoextraction of mercury and gold from cyanidation tailings of small-scale gold mining area of West Lombok, Indonesia. Adv. Environ. Biol. 2014, 1277-1285.

77. Alcantara, H.J.P.; Doronila, A.I.; Kolev, S.D. Phytoextraction potential of Manihot esculenta Crantz.(cassava) grown in mercury-and gold-containing biosolids and mine tailings. Miner. Eng. 2010, 114, 57-63. [CrossRef]

78. Moreno, F.N.; Anderson, C.W.; Stewart, R.B.; Robinson, B.H.; Nomura, R.; Ghomshei, M.; Meech, J.A. Effect of thioligands on plant-Hg accumulation and volatilisation from mercury-contaminated mine tailings. Plant Soil 2005, 275, 233. [CrossRef]

79. Whitehead, J.A.; Lawrance, G.A.; McCluskey, A. 'Green' leaching: Recyclable and selective leaching of gold-bearing ore in an ionic liquid. Green Chem. 2004, 6, 313-315. [CrossRef]

80. Jenkin, G.R.; Al-Bassam, A.Z.; Harris, R.C.; Abbott, A.P.; Smith, D.J.; Holwell, D.A.; Chapman, R.J.; Stanley, C.J The application of deep eutectic solvent ionic liquids for environmentally-friendly dissolution and recovery of precious metals. Miner. Eng. 2016, 87, 18-24. [CrossRef]

81. Amankwah, R.K.; Styles, M.T.; Nartey, R.S.; Al-Hassan, S. The application of direct smelting of gold concentrates as an alternative to mercury amalgamation in small-scale gold mining operations in Ghana. Int. J. Environ. Pollut. 2010, 41, 304-315. [CrossRef]

82. Nam, K.; Jung, B.; An, J.; Ha, T.; Tran, T.; Kim, M. Use of chloride-hipochlorite leachants to recover gold from tailing. Miner. Porcess. 2008, 86, 131-140. [CrossRef]

83. Radulescu, R.; Filcenco-Olteanu, A.; Panturu, E.; Grigoras, L. New hidrometallurgical process for gold recovery. Chimie si Ingeneria Mediului 2008, 53, 135-139.

84. Drouin, A.; Lemieux, D.; Lalancette, J.M.; Chouinard, C. Demonstration campaign results on a cyanide-free process for gold extraction from a refractory pyrite concentrate. In Proceedings of the SME Annual Conference and Expo 2017: Creating Value in a Cyclical Environment, Denver, CO, USA, 19-22 February 2017; pp. 172-176.

85. UNEP. Minamata Convention on Mercury: Text and Annexes; UNEP: Geneva, Switzerland, 2013. 